\title{
Effects of Macroeconomic Variables on Foreign Direct Investment in a Liberalized Economy: The Case of Nigeria
}

\author{
${ }^{1}$ P. C. Obidike \& ${ }^{2}$ K. E.Uma, \\ ${ }^{3}$ (Department of Banking and Finance, Abia State University, Uturu, Nigeria. \\ ${ }_{2}^{2}$ (Department of Economics \& Development Studies, Federal University, Ndufu Alike-Ikwo, Ebonyi State, Nigeria,
}

\begin{abstract}
The study investigated the impact of some selected macroeconomic variables on the attraction of foreign direct investment (FDI) in Nigeria between 1975 and 2009. Augmented Dickey-Fuller test was used to examine the time series property of the data and Johansen co-integration test was employed to ascertain the long-run relationship between the dependent variable (FDI) and the independent macroeconomic variables. Ordinary least technique also was employed in the study. Error correction coefficient was high, rightly signed and significant which reveals a long run relationship between the selected macroeconomic variables and FDI for the period of study. The explanatory variables included in the model showed statistical significant impact on FDI. The overall regression was significant as denoted by the probability of the F-statistic at 5\% significant level. On this note, among the recommendations made include: the Nigerian government should promote non-oil exports and discourage over dependence on imports of goods and raw materials; diversification of the economy should be paramount in the minds of the resource managers of our economy and it is imperative that the country has to promote private sector led growth and the creation of enabling environment, especially infrastructure.
\end{abstract}

Key words: effects, foreign direct investment, liberalized economy, macroeconomic variables

\section{Introduction}

The need for external capital inflows arise when desired national investments exceed actual savings. They are essentially necessary also owing to investments with long gestation periods that generate non-monetary returns; growing government expenditure that are not tax-financed and when actual savings are lower than potential savings owing to repressed financial markets, and even, capital flight. External capital flows could be of two types: official and private. Official flows can be multilateral, as when they originate from international agencies such as World Bank and IMF or bilateral, when they originate from one country to another in the form of loans or aid. Private flows can be debt creating and non-debt creating flows. They could take one of four types viz: Foreign Direct Investment, Portfolio Investment, International Bond and Equity Offerings, Commercial Bank loans and lending to Local Banks and private entities.

Capital flows arise from savings/investment imbalances across countries, which result in transfer of real resources through trade or current account transactions. This process is facilitated by economic globalization. In essence, therefore, the globalization process generally involves the deepening and widening of cross-border flow of trade, capital, labour and technology, which are facilitated by rapid communication mechanisms. In effect, innovations in communications and information technology combined with the liberalization and deregulation of the markets and economies of many countries have played the key role in fostering global economic integration by boosting trade and investment capital flows.

Several studies, including [1] have provided evidence of a huge and increasing degree of international capital mobility among major industrial countries and among emerging market economies which offer high returns, ensure macroeconomic stability and liberal trade regimes as well as financial restriction and offer free access to listed stocks.

Developing countries are characterized by low level of domestic savings and in order to attain the desirable level of investment would need foreign savings to bridge the savings-investment gap. These savings that come in the form of "new money" or capital inflows are expected to provide finance for economic activities. Sometimes, these inflows may come in the form of credit from parent companies or affiliates to shore up the capitalization of the domestic companies.

The operational rules of the World Bank, IMF and World Trade Organization (WTO) as well as those of some regional trade arrangements have often imposed current and capital accounts liberalization as prerequisites for participating in international trade and investment. Consequently, such liberalizations are generally embedded in 
international standards and codes as best practices expected of developing countries engaging in inter-governmental and non-governmental international relations.

Over the last three decades, developing countries have taken advantage of the opportunities offered by globalization to enhance their rapid and sustainable growth as well as rapid integration into the global economy. This has triggered phenomenal increase in international financial transactions.

Globalization as a process is one of those dynamic and significant elements of growth in international capital flows which arise from capital account liberalization. Globalization is therefore often seen as an inevitable path to economic development for developing countries. Emerging and developing economies have always been advised to open up to foreign capital flows through the liberalization of the capital account transactions. This is based on the premise that liberalizing capital account would permit financial resources to flow from capital surplus countries, where expected returns are low, to capital deficit countries where expected returns are high. These can be well achieved by capital account liberalization which is a systematic and progressive removal of administrative and legal restrictions on international capital transactions and the implementation of various macroeconomic policy reforms. Stronger inflows would be realized as international investors and residents who had placed their capital abroad react to the improved investment environment.

Experience has shown that some countries in Asia, notably, South Korea, Taiwan and Hong Kong in part financed their economic development with foreign capital. Even the developments in Central and Eastern Europe, have given credence to the importance of foreign capital flow in economic development of nations. Capital inflows in those emerging European countries generated multiplier effects and enhanced the level of output and domestic savings.

There is a wide spread acceptance among economists that successful capital account liberalization should be preceded by macroeconomic stabilization, domestic financial sector reform, current account liberalization and prudential regulation of the financial sector $\{[2],[3]$ [4], [5] [6]\}.

Capital account liberalization is a necessary strategy for attracting foreign private capital flows. [7], [8] suggest that liberalization of capital account would lead to global economic efficiency and facilitate the allocation of world savings to those who are able to use them most productively. It is argued that developing countries can only benefit from large capital inflows when they formulate and implement sound macroeconomic, fiscal, banking, capital market policies and some other institutional and regulatory reforms. As argued by [9], the major benefits of capital account liberalization to developing countries may be obtained not from its direct contribution to increased (GDP) growth or reduced consumption volatility, but rather from its capacity to provide a set of "collateral" benefits of facilitating the transfer of managerial, technological know-how and capital accumulation. The liberalization of these transactions is expected to improve a country's balance of payments, smoothen temporary shocks on income and consumption, reduce borrowing costs and spur economic growth.

The Nigerian Investment Promotion Commission Act No.16 of 1995 was primarily established to give mandate for the promotion of foreign private investment in the country. In the same year, the Foreign Exchange Monitoring and Miscellaneous Act No 17 were promulgated to complement that of No 16. The recent banks consolidation which brought the existing banks from 89 to 24 mega banks through liquidation, merger and acquisition, institutional reforms, due process, corporate governance, legal documentation, market development, financial education, training of market operators, among others were also in place. In spite of these liberalization reforms, not much foreign capital is attracted to Nigeria for development purposes.

This is unlike what obtained in the Asian countries of South Korea, Taiwan, Hong Kong, Malaysia, Indonesia and Thailand. Capital flow to these countries have been on the increase from 1986, averaging 30 percent, between 1986 and 1994, climbing up to 97.3 percent in 1995. Over the same period, capital inflow of just 3.7 percent went to sub - Saharan Africa while only a trickle of 1.6 percent to Nigeria [10]. Flows to Sub-Saharan Africa (SSA) as at 1987 have not been more than 9.75 percent. For Nigeria, there has been a steady fall from the level of 7.3 percent in 1989 to 1.56 percent in 1994, between 1997 and 2001 it averaged 27.1 percent and in 2005, it was 17.9 percent [11]. In view of this, the study goes to evaluate empirically the impact of macroeconomic variables in the liberalized capital account and the attraction of foreign direct Investment - FDI in Nigeria

But, in spite of Nigeria's sound, robust and improved macroeconomic, fiscal, capital market policies, banking and domestic financial sectors reforms and overhaul, various institutional changes, government policy reversals and prudential regulations of regulatory bodies, there has been no appreciable change in the inflow of Foreign Direct Investment (FDI) in Nigeria. All these could not change or increase the amount of Foreign Direct Investment in Nigeria. To this end, an evaluation of the efficiencies and effectiveness of some major macroeconomic variables for the promotion and maximization of capital inflow through the liberalization of Nigeria's capital and financial transactions will be the focus of this study. 
The main objective of this study is to evaluate the effectiveness of the macroeconomic variables in the liberalized capital account on the attraction of Foreign Direct Investment (FDI) in Nigeria between 1975 and 2009. The paper will be presented in this order: section one focuses on review of literature; sources, nature of data and methodology will constitute section two; section three will dwell on result presentation and discussion while the last section four is recommendations and conclusion.

\section{Review Of Literature}

The concept of capital account is best understood in the context of a country's balance of payments (BOP). A country's BOP is a record of transactions between its residents and non-residents. The BOP has two major accounts namely the current and the capital accounts. The current accounts transactions include trade in goods (visible), trade in services (invisibles), payments of factor incomes (dividends, interest and migrants' remittances from earnings abroad) and international transfers (gifts). The capital account records transactions, which do not involve the receipt of income, but change the form in which assets are held.

Capital Account Liberalization (CAL) is the process of removing restrictions from international transactions related to the movement of capital. It can involve the removal of controls on both domestic residents' international financial transactions and investments in the home country by foreigners. Liberalization can apply to both inflows and outflows of capital. [12] points that capital account liberalization in a generic sense is about allowing capital to flow freely into and out of a particular country. This connotes a deliberate policy that allows domestic businesses to borrow from foreign banks, foreigners are allowed to purchase domestic debt instruments as well as invest in the domestic stock market.

[13], refer capital account liberalization as the freedom from prohibitions on transactions on the capital and financial accounts of the balance of payments which entails lifting of restrictions on foreign capital inflows and outflows. However, our working definition of capital account liberalization (CAL), is the freedom to convert local financial assets into foreign financial assets and vice versa at market determined rates of exchange. It is associated with changes of ownership in foreign/domestic financial assets and liabilities and embodies the creation and liquidation of claims on or by the rest of the world.

Developing countries as well as other member countries of the International Monetary Fund (IMF) have always been encouraged to open up to foreign capital flows through the liberalization of their capital account transactions. The IMF conditionalities, World Trade Organization (WTO) rules and some regional trade arrangements have often spelt out capital account liberalization as a prerequisite for participating in trade and investment. Consequently, capital account liberalization is embedded in international standards and codes as best practice necessary for developing countries engaging in inter-governmental and non-governmental international relations. In the days of [3], financial and capital account liberalization theory has advanced from focusing merely on credit markets and the public sector to include the private sector. Against this backdrop, they referred to capital account liberalization as a policy, which a government gives foreign investors the right to purchase shares and bonds in the country's markets, at the same time granting domestic investors the right to trade in foreign securities. Advocates for liberalization argue that unlimited international capital flows resulting from liberalization, lower the cost of capital, allow for risk diversification, and encourage investment in projects with higher returns. This is why [14], took capital account liberalization to mean eliminating the rules and regulations in developing countries that could storm the flows of speculative and volatile hot money - short - term loans and contracts that are usually no more than bets on exchange rate movements - into and out of countries. Correspondingly, a liberalized or open capital market is one which individuals and firms can access international financial markets freely.

An open capital account implies capital account convertibility, which refers to freedom to convert local financial assets into foreign financial assets, and vice versa, at market determined exchange rates. A country is said to have achieved full currency convertibility of its currency when residents and non-residents are allowed to convert the local currency, at prevailing exchange rates, into foreign currencies and to use the later freely for international transactions ([15], [16]).

The flows of capital-debt, portfolio equity and direct and real estate investment between one country and others are recorded in the capital account of its balance of payments. Outflows include resident's purchases of foreign assets and repayment of foreign loans; inflows include foreigners' investments in home country financial markets and property and loans to home -country residents.

Classic economic theory argues that international capital mobility allows countries with limited savings to attract financing for productive domestic investment projects that it enables investors to diversify their portfolios, that is spread investment risk more broadly, and that it promotes inter-temporal trade, the trading of goods today for goods in the future. 
[7], [8] suggest that the benefits of liberalizing capital account outweigh the potential costs. Citizens of countries with free capital movements would also enable corporations in these countries to raise capital in the international markets at a lower cost. Low levels of capital openness are associated with low levels per capita income; lower levels of trade openness, weaker financial development, higher levels of inflation, fixed exchange rates, and higher premium on the black market for foreign currencies. This is what [3] called financially repressed economy and also are referred to as politically repressed economies.

[17] study on Egypt capital account liberalization reveals that savings increased by 6.0 percent of gross domestic product (GDP). The empirical study attested to the fact that changes in the index of financial openness, as a proxy for capital account liberalization, have positive correlation with growth, and the opening of stock markets to foreign participation is directly associated with investment booms.

[18] found no association between the levels of capital account openness and economic growth, a finding that [19] replicated and extended. [20] showed that changes in capital account openness (liberalization) were associated with higher long - run growth. Focusing on emerging markets, it was also found that incidences of financial liberalizations were associated with subsequent economic growth.

In some studies of openness on growth and the channels through which openness might produce growth, [21] finds scant evidence of the effects of openness on investment. [22] show that openness leads to financial "deepening" but only for advanced industrial nations. Hence, they propose that emerging market nations lack some key political economic institutions through which openness might act beneficially, which implies that openness has a contingent relationship to growth. [22], [23] among others found that financial or capital account or stock market liberalization leads to growth. [24] finds that liberalization leads to growth in middle to high-income countries. [25] revisit Edwards study, and while they reject his findings on methodological and other grounds, they suggest that liberalization does have a contingent relationship with growth.

[26], [27] in their works confirmed that capital account liberalization is a necessary strategy to attract private capital flows to substitute declining aids in developing countries. Capital account liberalization in these studies, correlated with growth as well as the deepening of the financial sector.

\section{Sources Of Data And Methods Of Data Collection}

The study relied essentially on secondary data which was sourced from various publications. Specifically, data was obtained from various issues of: Central Bank of Nigeria (CBN) Statistical Bulletin, Annual Reports and Statements of Accounts as well as the Economic and Financial Reviews of the CBN; publications of the National Bureau of Statistics (NBS); publications of the Federal Ministry of Planning, Economic Development and Finance. Nigerian Deposit Insurance Corporation (NDIC). Other sources included: The World Bank Policy Research Working Papers, United Nations Conference on Trade and Development (UNCTAD) Publications, IMF and OPEC Working Papers.

\section{Model Specification/Formulation}

Increase in aggregate economic activity impact significantly on gross domestic product (GDP). An increase in the GDP represents a favourable change in market size and income, which is expected to attract FDI. Furthermore, a rise in GDP signals positive growth in the economy. Price stability is an essential ingredient in the attraction of foreign direct investment as it promotes investors confidence. While high rate of inflation and price instability could erode profit and even capital. The level of exchange rate influences FDI inflows because, depreciation of the host country currency against the home country of the foreign investor, increases the relative wealth of foreigners thereby increasing the attractiveness of the host country for foreign investment. The implication is that depreciation of the currency of the host economy enables the foreigners to acquire more assets cheaply. While appreciation in the host economy makes it difficult for foreign investors to acquire assets from the host country.

With capital account liberalization, the level of international reserve becomes a key consideration for policy makers. Reserves help to cushion the impact of cyclical changes in the balance of payment and help offset unanticipated shocks, which can lead to reversals of capital flows. Reserves also help sustain confidence on both domestic policy and exchange rate policy. Since government is the greatest provider of amenities, and infrastructures, the higher the level of government spending, the higher the living standard of the citizenry. Nigeria has experienced current account surpluses as it experienced deficits.

A country with current account surpluses would be using some of the output to build up claims on the outside world. A growing country like Nigeria should be trying to acquire additional resources for capital formation in order to promote development. Nigeria should rather run current account deficits and build up debts to the outside 
world. This is what countries like USA did for most of the nineteenth century. A current account deficit is not bad if it can be financed on acceptable terms and if the proceeds of borrowing are used effectively.

Open economies encourage more foreign investments. One indicator of openness is the relative size of the export sector. A decrease in tariffs will increase openness and vice-visa. Openness promotes the efficient allocation of resources through comparative advantage, allows the dissemination of knowledge and technological progress and encourages competition in domestic and international markets.

Government overall fiscal policy deficit (-) or surplus (+) stands as a proxy for government fiscal discipline (GFD). Fiscal discipline gives a signal to investors as to the health of the economy. Moreover, if the fiscal situation is not under control, Central Bank policies can become inefficient because of the lack of fiscal discipline. Government fiscal discipline is a measure of macroeconomic stability which exerts enormous influence on Foreign Direct Investment decision in the host economy.

The functional relationship between the dependent and independent variables in this study is as follows:

$Y_{i}=\beta_{o}+\beta_{1} X_{1}+\beta_{2} X_{2}+\ldots \beta_{n} X_{n}+U_{i} \ldots-\ldots(1)$

Where

$\mathrm{Y}$ is the dependent variable. $\mathrm{X}_{1}-\mathrm{Xn}$ are the explanatory or independent variables (or regressors)

$\mathrm{U} \quad$ is a stochastic, error or disturbance term

$\mathrm{i}$ the $\mathrm{i}^{\text {th }}$ observation

$\mathrm{t} \quad$ the $\mathrm{t}^{\text {th }}$ observation

$\beta_{1} \beta_{\mathrm{n}} \quad$ are regression coefficients.

$\beta_{\mathrm{o}} \quad$ the constant term

FDI $=f($ GDP, INF, EXR, FER, TGEXP, CAB, TO, GFD)

$\mathrm{FDI}_{\mathrm{t}}=\beta_{\mathrm{o}}+\beta_{1} \mathrm{GDP}_{\mathrm{t}}+\beta_{2} \mathrm{INF}_{2 \mathrm{t}}+\beta_{3} \mathrm{EXR}_{3 \mathrm{t}}+\beta_{4} \mathrm{FER}_{4 \mathrm{t}}+\beta_{5} \mathrm{TGEXP}_{5 \mathrm{t}}+\beta_{6} \mathrm{CAB}_{6 \mathrm{t}}+\beta_{7} \mathrm{TO}_{7 \mathrm{t}}+\beta_{8} \mathrm{GFD}_{8 \mathrm{t}}+\mathrm{U}_{\mathrm{t}} \ldots(2)$

Where

FDI $_{\mathrm{t}} \quad=$ Foreign Direct Investment in periods t. A proxy for the extent of Capital Account Liberalization.

$\mathrm{GDP}_{\mathrm{t}} \quad=$ Gross Domestic Product in periods $\mathrm{t}$.

$\mathrm{INF}_{2 \mathrm{t}} \quad=$ Annual rate of inflation in period $\mathrm{t}$.

$\mathrm{EXR}_{3 \mathrm{t}} \quad=$ Exchange rate between the Nigerian naira and US Dollar in period t.

$\mathrm{FER}_{4 \mathrm{t}} \quad=$ Foreign Exchange Reserve in period $\mathrm{t}$.

TGEXP $_{5 \mathrm{t}} \quad=$ Government Total Expenditure in the economy in period $\mathrm{t}$.

$\mathrm{CAB}_{6 \mathrm{t}} \quad=$ Current Account balances in period $\mathrm{t}$, the capital account liberalization depends on the extent of the liberalization of $\mathrm{CAB}$.

$\mathrm{TO}_{7 \mathrm{t}} \quad=$ The share of total trade in Gross Domestic Product (GDP) in periods t. (TT/GDP)

$\mathrm{GFD}_{8 \mathrm{t}} \quad=$ Government Fiscal Discipline

$\mathrm{U}_{\mathrm{t}} \quad=$ Error term or stochastic variable (s).

$\beta_{1-} \beta_{8} \quad=$ Coefficients of the independent variables.

\section{V . Apriori Expectations}

On apriori basis, the regression parameter GDP is expected to be greater than zero - ie $\beta_{1}>0$. The relationship between GDP and FDI is expected to be positive. For inflation rate (INF), the regression parameter is expected to be less than zero - ie $\beta_{2}<0$. The regression parameter $\beta_{3}(\mathrm{EXR})$ is expected to be less than zero ie $\beta_{3}<0$ Exchange rate is the key price variable in the economy and performs dual role of maintaining international competitiveness, and serving as a nominal anchor for domestic prices. Therefore, the relationship between Exchange rate appreciation and FDI is expected to be negative. The model parameters FER is expected to be more than zero ie $\beta_{4}>\mathrm{O}$. The relationship between foreign exchange reserve (FER) and FDI inflow is expected to be positive. The parameter (TGEXP) is expected to be greater than zero- ie $\beta_{5}>0$. The relationship between total Government Expenditure (TGEXP) and FDI is expected to be positive. The model parameter CAB is expected to be less than zero - ie $\beta_{6}<\mathrm{O}$. When the model parameter $\beta_{6}>0$. The model parameter (TO) is expected to be more than zero- ie $\beta_{7}>0$. The relationship between openness (market size) and FDI inflow is expected to be positive. The model parameter, government fiscal discipline (GFD) is expected to be more than zero ie $\beta_{8}>0$ in a fiscally disciplined economy. This shows that the relationship between FDI and government fiscal discipline is positive but negative when there is fiscal indiscipline 


\section{Method Of Study}

The statistical tools employed in the study were the ordinary least square (OLS), co-integration and error correction model (ECM) techniques of econometric analysis.

\section{Unit Root Test Results}

Scholars have pointed that most time series variables are non-stationary and using non-stationary variables in a model might lead to spurious regressions. Unit root test was employed to determine the time series characteristic of the variables.

The summarized result represented in table 1 shows that at various critical levels $(1 \%, 5 \%$ and $10 \%)$, all the variables were found to be integrated at order one, ie I (1).

\begin{tabular}{clcc}
\multicolumn{5}{c}{$\begin{array}{c}\text { Table } 1 \text { AUGMENTED DICKEY FULLER (ADF) TEST FOR STATIONARITY } \\
\text { VARIABLES }\end{array}$} & ADF & $\begin{array}{l}\text { ORDER } \\
\text { INTEGRATION }\end{array}$ \\
& & & I $(1)$ \\
$\Delta$ & FDI & -4.62941 & $\mathrm{I}(1)$ \\
$\Delta$ & EXR & -3.83786 & $\mathrm{I}(1)$ \\
$\Delta$ & INFR & -6.19493 & $\mathrm{I}(1)$ \\
$\Delta$ & TGEXP & -4.44213 & $\mathrm{I}(1)$ \\
$\Delta$ & GDP & -3.21524 & $\mathrm{I}(1)$ \\
$\Delta$ & FER & -5.20594 & $\mathrm{I}(1)$ \\
$\Delta$ & TO & -4.77895 & $\mathrm{I}(1)$ \\
$\Delta$ & CAB & -6.20215 & $\mathrm{I}(1)$ \\
$\Delta$ & GFD & -4.95886 &
\end{tabular}

OF

This result suggests a long run relationship since all the variables are integrated of the same order. But it has to be confirmed using Johansen co-integration test.

\section{CO-Integration Test Result}

The Johansen co-integration test uses two statistics test namely: the trace test and the maximal Eigenvalue test. The first row in each of the table tests the hypotheses of no co-integrating relationship while the second row tests the hypothesis of one co-integrating relation and so on, against the alternative of full rank of co-integration. We present the results in table 2

Table 2: Co-integrating Test Result between FDI and Components of Macroeconomic variables

$$
5 \text { Percent } 1 \text { Percent Hypothesized }
$$

\begin{tabular}{|c|c|c|c|c|}
\hline Eigenvalue & $\begin{array}{l}\text { Likelihood } \\
\text { Ratio } \\
\end{array}$ & Critical Value & Critical Value & No. of CE(s) \\
\hline 0.988720 & 385.1839 & 192.89 & 204.95 & None $* *$ \\
\hline 0.887111 & 237.1887 & 156.00 & 168.36 & At most $1 * *$ \\
\hline 0.792284 & 165.2040 & 124.24 & 133.57 & At most $2 * *$ \\
\hline 0.715904 & 113.3417 & 94.15 & 103.18 & At most $3 * *$ \\
\hline 0.637124 & 71.81309 & 68.52 & 76.07 & At most $4 *$ \\
\hline 0.399529 & 38.36119 & 47.21 & 54.46 & At most 5 \\
\hline 0.291111 & 21.52982 & 29.68 & 35.65 & At most 6 \\
\hline 0.247528 & 10.17595 & 15.41 & 20.04 & At most 7 \\
\hline 0.023686 & 0.791049 & 3.76 & 6.65 & At most 8 \\
\hline
\end{tabular}

The above result denotes the existence of co-integration between foreign direct investment (FDI) and Gross Domestic Product (GDP), annual rate of inflation (INF), exchange rate (EXR), foreign exchange reserve (FER), current account balance (CAB), total government expenditure (TGEXP), trade openness(TO) and government fiscal discipline (GFD) at the period.. It shows the rejection of null hypothesis of no co-integration and acceptance of the alternative of co-integration. So, the results suggest existence of a stable long run relationship between FDI and components of macroeconomic variables. 


\section{Error Correction Model}

In order to develop the error correction model, the lagged residuals are incorporated in the OLS estimation, incorporating the first differences of all the variables and the differences of all variables from the co-integrating vector as independent variables. The methodology employed in deriving the preferred shot-run dynamic model is the generating specific approach. Initially, a highly general error correction model was specified, which included lags up to the second order. This general model was then tested in order to arrive at a parsimonious specification. The parsimonious results for the model are presented below.

\section{Parsimonious Regression Results}

\begin{tabular}{|c|c|c|c|c|}
\hline \multicolumn{5}{|c|}{$\begin{array}{l}\text { Dependent Variable: D(LOG(FDI)) } \\
\text { Method: Least Squares } \\
\text { Date: 11/01/11 Time: 12:00 } \\
\text { Sample(adjusted): } 1978 \text { 2009 } \\
\text { Included observations: } 32 \text { after adjusting endpoints }\end{array}$} \\
\hline Variable & Coefficient & Std. Error & t-Statistic & Prob. \\
\hline $\mathrm{C}$ & 0.142891 & 0.109286 & 1.307493 & 0.2121 \\
\hline D(LOG(FDI(-1))) & 0.335646 & 0.130587 & 2.570285 & 0.0222 \\
\hline D(LOG(FDI(-2))) & 0.266452 & 0.085097 & 3.131166 & 0.0074 \\
\hline $\mathrm{D}(\mathrm{LOG}(\mathrm{EXR}))$ & 0.649462 & 0.158223 & 4.104732 & 0.0011 \\
\hline D(LOG(INFR)) & 0.071621 & 0.054015 & 1.325962 & 0.2061 \\
\hline D(LOG(TGEXP)) & 0.545814 & 0.200242 & 2.725776 & 0.0164 \\
\hline D(LOG(TGEXP(-1))) & 0.608346 & 0.203599 & 2.987962 & 0.0098 \\
\hline $\mathrm{D}(\mathrm{LOG}(\mathrm{GDP}))$ & 0.659487 & 0.314046 & 2.099969 & 0.0543 \\
\hline $\mathrm{D}(\operatorname{LOG}(\mathrm{GDP}(-1)))$ & -2.298651 & 0.465184 & -4.941384 & 0.0002 \\
\hline $\mathrm{D}(\mathrm{LOG}(\mathrm{FER}))$ & 0.278836 & 0.088119 & 3.164306 & 0.0069 \\
\hline D(LOG(TO)) & 0.489205 & 0.183922 & 2.659845 & 0.0187 \\
\hline $\mathrm{D}(\operatorname{LOG}(\mathrm{TO}(-1)))$ & 0.213612 & 0.221911 & 0.962604 & 0.3521 \\
\hline $\mathrm{D}(\mathrm{LOG}(\mathrm{TO}(-2)))$ & 1.606003 & 0.242239 & 6.629842 & 0.0000 \\
\hline $\mathrm{D}(\mathrm{LOG}(\mathrm{CAB}))$ & -0.031569 & 0.028429 & -1.110457 & 0.2855 \\
\hline $\mathrm{D}(\mathrm{LOG}(\mathrm{CAB}(-1)))$ & -0.052435 & 0.026327 & -1.991650 & 0.0663 \\
\hline $\mathrm{D}(\mathrm{LOG}(\mathrm{GFD}))$ & -0.186083 & 0.059639 & -3.120144 & 0.0075 \\
\hline D(LOG(GFD(-1))) & -0.386373 & 0.068009 & -5.681170 & 0.0001 \\
\hline $\operatorname{ECM}(-1)$ & -0.990417 & 0.158317 & -6.255921 & 0.0000 \\
\hline R-squared & 0.961123 & Mean dependent var & & 0.255103 \\
\hline Adjusted R-squared & 0.913916 & S.D. dependent var & & 0.598619 \\
\hline S.E. of regression & 0.175635 & Akaike info criterion & & -0.342497 \\
\hline Sum squared resid & 0.431867 & Schwarz criterion & & 0.481980 \\
\hline Log likelihood & 23.47995 & F-statistic & & 20.35966 \\
\hline Durbin-Watson stat & 1.890135 & Prob(F-statistic) & & 0.000000 \\
\hline
\end{tabular}

From the above parsimonious long run model, Exchange Rate (EXR), Inflation Rate (INFR), Total Government Expenditure (TGEXP), Gross Domestic Production (GDP), Foreign Exchange Reserve (FER), Trade Openness (TO), Current Account Balance (CAB) and Government Fiscal Discipline explained 96.1\% change in Foreign Direct Investment (FDI). That is the explanatory variables included in the model explained significant changes in FDI. The overall regression was significant at $1 \%$. Error correction coefficient was high, rightly signed and significant. Some of the coefficients of the variables of interest have the expected signs while some do not.

Exchange Rate (EXR) appeared with a positive sign. This means that the apriori expectation was met. This is a clear indication of the depreciation of the domestic currency-naira against foreign currencies. This indicates that a unit increase in Exchange Rate (EXR) results in the increase of FDI by 0.6494.

The variable of Inflation Rate (INFR) does not meet with the apriori expectation because it showed a positive sign. The implication is that a unit increase in inflation brings about 0.0716 increase in FDI. This was as a result of the domestic inflation not affecting international transactions. There was so much money in the economy occasioned by the oil boom. And because Nigeria is an oil economy, foreigners did not mind its domestic monetary conditions. 
The Total Government Expenditure has a positive sign, matching with the economic expectations. The implication is that as government increases its expenditure on providing amenities, infrastructures that will be attracting FDI. It is also positive in its lag 1 showing 0.6083.

The current value of GDP shows positive sign according to the apriori expectations. The lagged value of -2.2986 shows that a unit increase in GDP brings about a decrease in FDI of 2.2986 indicting that the economy was readjusting for better but could not attract foreign investment because, government could not manage the economy with some level of transparency hence Nigeria's high rating in corruption. Then the anti -corruption Act was not instituted.

The Foreign Exchange Reserve has its current value as positive which corresponds with the apriori expectation. This explains that a unit increase in the foreign reserves will bring about an increase in the FDI to the tune of 0.2788 , showing sustenance on both domestic and exchange rate policies.

The total Trade Openness, (TO), has its current value as positive, showing 0.4892 to mean that a unit increase in Trade Openness will result in an increase in FDI to the tune of 0.4892 . The lagged values of (TO) in 1 and 2 also showed positive signs tallying with the apriori expectation. After the establishment of Acts 16 and 17 and foreign exchange (monitoring and miscellaneous Acts) in 1995, the share of trade increased. Current and lagged values in $\mathrm{CAB}$ indicated negative signs. This established the fact that Nigeria was producing much for the outside world but only that proceeds were on foreign goods and services, without using the funds for economic management.

The current and lagged 1 values of GFD are both negative signs. This shows that a unit increase in GFD brings about a reduction in FDI inflow. Fiscal Discipline increases foreign investors, but in the Nigerian case, there has never been Fiscal discipline in both military and civilian regimes.

The overall regression is very significant at $1 \%$ with $\mathrm{F}$-value of 20.35966 and $\mathrm{R}^{2}$ of $96.11 \%$ which showed that the selected variables accounted for the changes and variations in FDI while other factors not captured in the model accounted for only $3.89 \%$. This showed that the regression line is well fitted. Adjusted R-squared confirmed this by its value of $91.3 \%$. The overall regression is significant given the probability of the F-statistic.

\section{Recommendations}

On the basis of the outcome of our analysis the following recommendations are necessary.

(i)The Nigerian government should promote non-oil exports and make sure that there is a reduction in the dependence on imports of goods and raw materials.

(ii) The diversification of the economy should be paramount in the minds of the managers of our economy. This will help in the attraction of FDI should the country specialize in certain productions. Cassava production in the country has evidenced this.

(iii) It is imperative that the country has to promote private sector led growth and the creation of enabling environment, especially infrastructure for the private sector in Nigeria to be intensified.

(iv) There is the need for proper management of exchange rate, reserves, interest rate, transparent privatization process, combating corruption, enforcing civil service and judicial reforms and adequate maintenance of security of life and property.

(v) The country should plan to reduce the level of budget deficit owing to improper management and improve on financial discipline through accountability and transparency in resources allocation.

(v) There should be proper management of our foreign debts to ensure that debts do not accumulate again. As in other liberalized countries, more ports and export free zones should be built.

\section{Conclusion}

There is large consensus that FDI is positive, subject to the presence of a sufficient level of human capital, depth of domestic financial integration, quality of governance and other macroeconomic conditions in the host country.

Apart from having the absorption capacity in the home country, in Nigeria's case, the desired policies are not in place - major basic enterprises were wholly owned by government which significantly reduces the role of FDI attraction. In Nigeria's development efforts investment policies have been interpreted as not being friendly. However, literature has it that for any country to succeed in the speedy attraction of FDI, the country must sequentially adopt their policies with banking and financial reforms coming first. Nigeria is yet to get over its banking and financial reforms.

At a more general level, the importance of a country's absorptive capital has been recently highlighted by several empirical studies. It was found out that international flows of capital stimulate productivity spill over only in 
those countries with adequate pre-conditions in place. Therefore, even if the process of international financial integration may channel additional capital to the developing world, its potential benefits cannot completely be accomplished in the absence of sufficient domestic pre- conditions. This line of reasoning has been reinforced by some recent insights in respect for property rights, the degree of transparency of the economy, the control of corruption and the level of financial sector supervision as pre-conditions.

Recent empirical studies have highlighted that good governance increases a countries ability to benefit from foreign capital and reduces the probability of crisis. Foreign Direct Investment, which has the highest potential growth effect among different types of capital flows tend to be concentrated in countries with corruption under control. It is therefore absolute necessary for Nigeria to tackle corruption in all ramifications through sincere reforms, re-orientation and attitudinal change of the habitants of the country.

\section{References}

[1] Montiel, P, "Capital Mobility in Developing Countries", Paper 1103, World Bank, Washington D.C. 1993.

[2] Fischer \& Rasin, Financial Opening: Why, How, When. Occasional Paper No 55, InternationalCentre for Economic Growth, San Francisco, California: ICS Press, 1994.

[3] McKinnon. R et al (1973), "Money and Capital in Economic Development, Washington D.C: Brooklings Institution.

[4] Mckinnon, R.I, The Order of Economic Liberalization $2^{\text {nd }}$ Edition, Baltimore MD. The John Hopkins University Press, 1993.

[5] Frenkel, J, "The Order of Economic Liberalization" In K Brunner and A. Meltzer (Eds), Economic Policy in a World of Change. Rochester Conference Series on Public Policy, Amsterdam North Holland, 99- 102, 1982.

[6] Edwards, S, The Order of Liberalization of the External Sector in Developing Countries, Prince Essays in International Finance no 156, Princeton: Princeton University, 1984.

[7] Fisher, S, Capital Account Liberalization and the Role of the IMF In: Should the IMF Pursue Capital Account Convertibility? Princeton University, Essays in International Finance, 1998.

[8] Fischer, S, "Capital Account Liberalization and the Role of the IMF" In: Should the IMF pursue Capital Account Convertibility? Princeton University, Essays in International Finance 207, 1-10, 1999.

[9] Kose, et al, Financial Globalization: A Reappraisal IMF Working Paper WP/06/186, 2006.

[10] Essen E.A. and E.A. Onwioduokit, "Capital Flows to Nigerian: Issues and Determinants" CBN Economic and Financial Review,37( 1), 1999.

[11] UNCTAD, Trade and Development Report, 1997

[12] Henry Peter (2003b). "Capital Account Liberalization, The Cost of capital and Economic Review, 91- 96, 2003

[13] Eichengreen, B et al, "Capital Account Liberalization: Theoretical and Practical Aspects. IMFOccasional Paper 172 (Washington D.C, IMF), 1989 .

[14] Stiglitz, J, Globalization and its Discontents, New York, Norton MW, 2002.

[15] Nsouli, S.M and Rached, M, "Capital Account Liberalization in the Southern Mediterranean" Finance and Development, 35 (4), 1998.

[16] Obadan, M. I, "Financial Globalization in Sub-Saharan Africa" A Research Report Prepared at the United Nation's African Institute for Economic Development and Planning, Dakar, June 2005.

[17] Hussain M, Financial Liberalization Currency substitution and Investment: The Case of Egypt". African Development Bank Research Paper 24,1996.

[18] Grilli, and Milesi- Feretti,. "Economic Effects and Structural Determinants of Capital Controls," IMF Staff Papers 42(3): 517-551, 1995.

[19] Rodrik, D, "Who Needs Capital Account Convertibility?" In "Should the IMF Pursue Capital Account Convertibility" Princeton Essays in International Finance, 207, Princeton, 1998.

[20] Quinn, D, "The Correlates of Change in International American Political Science Review, 91 (3),1997.

[21] Kraay Aart, "In Search of the Macroeconomic Effects of Capital Account Liberalization "Manuscript, The World Ban, 1998.

[22] Klein, M and Olivei, G, "Capital Account Liberalization - Financial Depth and Economic Growth". NBFR Working Paper 7384, 1999.

[23] Levin, R and Zervos, "Stock Market, Ranks, and Economic Growth American Economic Review, 88,. 537-57, 1998.

[24] Edwards, S, "Capital Mobility and Economic Performance: Are Emerging Economics Different? NBER working paper No.8076. Cambridge National Bureau of Economic Research, 2001.

[25] Arteta et al, "On the Growth Effect of the Capital account Liberalization (unpublished Berkley, California, University of California, 2001.

[26] Henry, P," "Do stock Market Liberalization Course Investment Booms” Stanford University Graduate School of Business Research Paper No. 1504, 1997.

[27] Demirguc-Kunt \& Detragiache, "Financial Liberalization and Financial Fragility”. University of Califonia, Santa Cruz, Working Paper $318,1998$. 